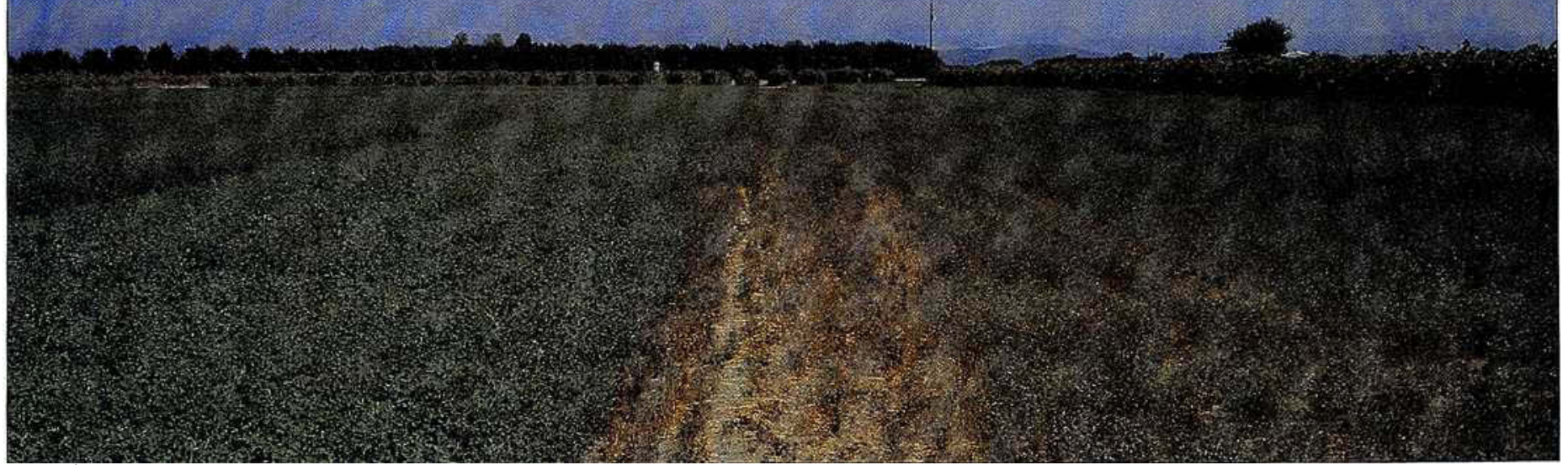

\title{
1. Imposed drought stress has no long-term effect on established alfalfa
}

\author{
Carol A. Frate $\square$ Bruce A. Roberts $\square$ Vern L. Marble
}

\begin{abstract}
Reducing or terminating irrigation on established alfalfa during summer months for two consecutive years reduced crop yields but had no long-term effects on the productive capability of the stand in the third year. Hay quality was negatively affected only when alfalfa was severely water-stressed.
\end{abstract}

In the South San Joaquin Valley, water can be the largest single cost of alfalfa production. Farmers apply 40 to 60 acre-inches in a normal year to obtain optimum yields. When precipitation falls below normal and irrigation districts cut back water deliveries, growers must manage with limited supplies. Water restrictions are likely to continue. Even in normal rainfall years ground water use by farms and cities exceeds annual recharge capacity in the South San Joaquin. Continued ground water depletion poses serious implications for both farms and cities which rely heavily on this water supply. We evaluated several options for farming with limited irrigation water, and assessed their long-term impact on alfalfa production and quality.

\section{Methods}

The alfalfa variety CUF 101, termed "very nondormant" for its tendency to grow in fall and winter, was planted in October, 1985 at the Kearney Agricultural
September 1987 photograph of alfalfa irrigation trials at Kearney Agricultural Center. Check at upper left was irrigated throughout the summer; check at lower left was not irrigated in July and August, but watering resumed in early September; check on the right had not been irrigated since June.

could not be followed due to physical limitations of the irrigation system such as pipe availability and seasonal variability. Exact numbers of irrigations relative to harvest dates are shown in table 1. Total irrigation amounts were measured using an in-line flow meter. Applications to individual plots were estimated based on uniform set times. Commercial equipment was used to cut, rake, bale, and remove alfalfa. Plots were marked with straw to identify treatment boundaries. Straw markers identified partial bales from adjoining plots. Plot yields were measured by weighing random bales to determine average bale weight and then counting bales from each plot. Core samples from random bales were taken for determination of moisture, crude protein, modified crude fiber (MCF), and acid detergent fiber (ADF) to predict total digestible nutrients (TDN). Quality analyses were performed by Dairymen's Creamery Cooperative Association, Tulare, using near infrared reflectance (NIR) spectroscopy.

\section{Results and conclusions}

Treatment yields by cutting for each year are shown in figure 1. Irrigating three times per cutting in June, July, and August had no effect on yields compared to the standard treatment of two irrigations per cutting in 1986 and 1987. Irrigating once per cutting (dry treatment) reduced yields by $21 \%$ during the high water use months of July and August in 1986. In 1987 the dry treatment produced less than the standard and wet treatments in July and August, but these differences were not significant. By the last cutting in early October, the dry treatment produced $19 \%$ less than treatments watered two or more times per cutting during the summer.

Yields were reduced in July and $\mathrm{Au}-$ gust for the skip treatment and from July 
through the rest of the season in the termination treatment. The mid-season termination of irrigation also affected the recovery and yield of alfalfa in the cutting immediately following rewatering. However, by the second cutting after irrigation was resumed, skip and termination treatments produced yields equivalent to the wet treatment. The July-August skip treatment yielded as well as the dry (single) treatment at the final fall cutting and achieved full production by the first cutting of the following year. For the termination treatment, yields were reduced at the first cutting of the next year, but second cutting yields were equal to other treatments.

In 1988 when treatments were irrigated uniformly, yields at each cutting were similar for all treatments except for the first cutting. The first harvest of the termination treatment did not yield as much as other treatments.

Seasonal totals are shown in table 2. There were no significant differences between standard and wet treatments in the 3 years of the trial. For other treatments, yields decreased as applied water decreased. The dry treatment in 1986 produced $85 \%$ of the yield with only $62 \%$ of

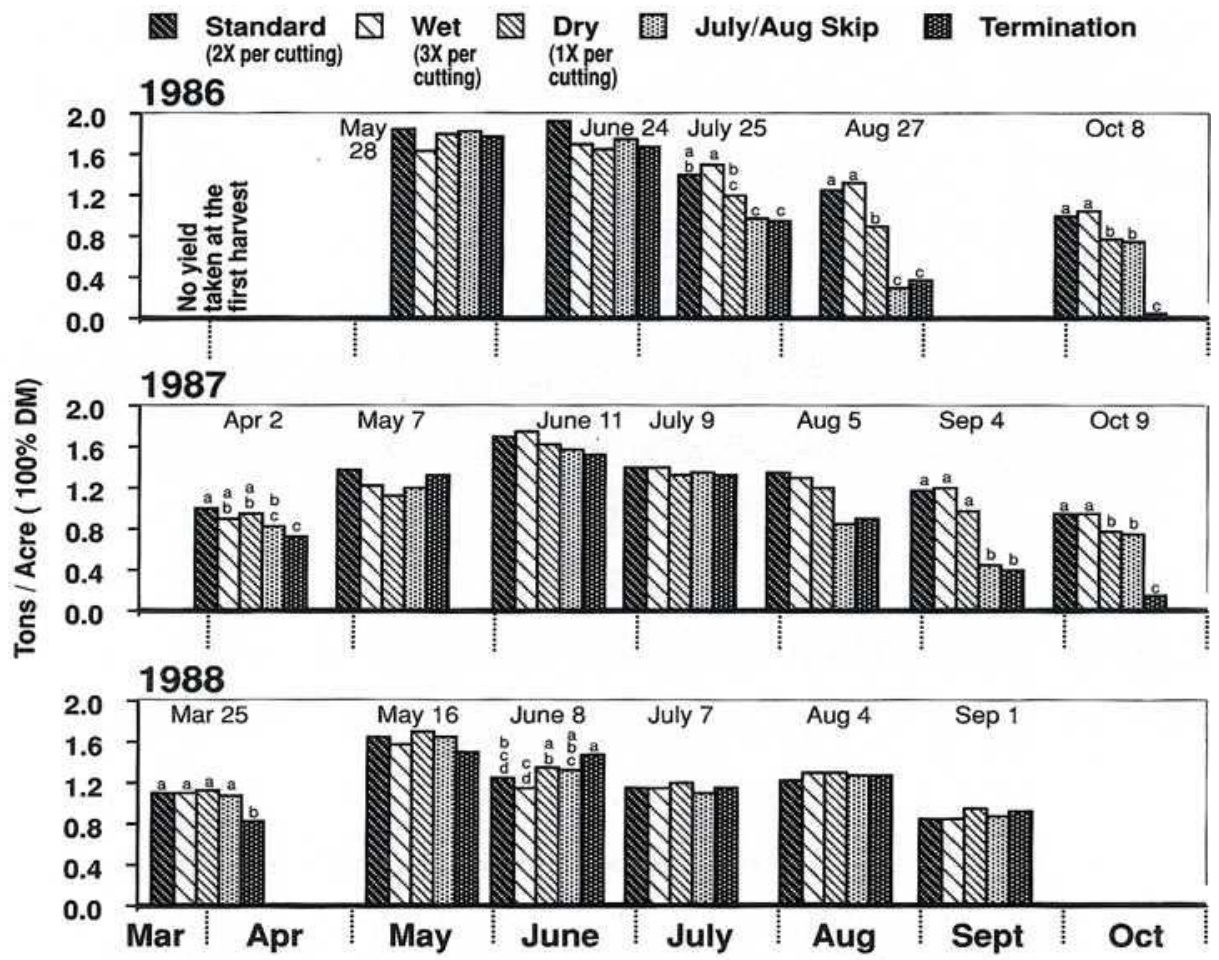

Fig. 1. Yields by cutting for each year of alfalfa irrigation study, 1986-1988. For each cutting date, columns with the same letter represent values that do not differ significantly at the $5 \%$ level of probability using LSD. Where no letters are present, treatments did not differ significantly.

\begin{tabular}{|c|c|c|c|c|c|c|c|c|c|c|c|}
\hline \multicolumn{6}{|c|}{$\begin{array}{l}\text { TABLE 1. Number of irrigations per treatment in alfalfa irrigation study } \\
\text { planted October } 1985 \text { at Kearney Agricultural Center, Parlier, California, } \\
1986-1988\end{array}$} & \multicolumn{6}{|c|}{$\begin{array}{c}\text { TABLE 2. Total annual yield ( } 100 \% \text { DM), applied water, and applied water per } \\
\text { ton for } 3 \text { years of alfalfa irrigation study, Kearney Agricultural Center, Parlier, } \\
\text { California* }\end{array}$} \\
\hline & \multirow{2}{*}{ Standard } & \multirow{2}{*}{ (2) } & \multirow{2}{*}{ Dry } & \multirow{2}{*}{$\begin{array}{l}\text { (4) } \\
\text { July-Aug } \\
\text { skip }\end{array}$} & \multirow{2}{*}{$\begin{array}{l}\text { (5) } \\
\text { July } \\
\text { termin- } \\
\text { ation }\end{array}$} & \multirow[t]{2}{*}{ Treatments } & \multicolumn{2}{|c|}{ Yield $(100 \%$ DM) } & \multicolumn{2}{|c|}{ Water Applied } & \multirow{2}{*}{$\begin{array}{c}\begin{array}{c}\text { Water } \\
\text { applied }\end{array} \\
\text { inches/ton }\end{array}$} \\
\hline & & & & & & & tons/acre & $\%$ & inches & $\%$ & \\
\hline 1986 & & & & & & & & & $86+$ & & \\
\hline Prior to $5 / 28$ harvest & 2 & 2 & 2 & 2 & 2 & (1) Standard & $7.42 \mathrm{a}$ & $(100)$ & 37 & $(100)$ & 5.0 \\
\hline Prior to $6 / 24$ harvest & 2 & 2 & 1 & 2 & 2 & (2) Wet & $7.28 \mathrm{a}$ & (98) & 51 & (138) & 7.0 \\
\hline Prior to $7 / 25$ harvest & 2 & 3 & 1 & 0 & 0 & (3) Dry & $6.32 \mathrm{~b}$ & (85) & 23 & (62) & 3.6 \\
\hline Prior to $8 / 27$ harvest & 2 & 2 & 1 & 0 & 0 & (4) July/Aug skip & $5.59 \mathrm{c}$ & (75) & 19 & (51) & 3.4 \\
\hline Prior to $10 / 8$ harvest & 2 & 3 & 1 & 1 & 0 & (5) July termination & $4.83 \mathrm{~d}$ & (65) & 15 & (41) & 3.1 \\
\hline $\begin{array}{l}\text { Total applied water } \\
\text { acre-inches }\end{array}$ & 37 & 51 & 23 & 19 & 15 & $\begin{array}{l}\text { LSD. } 05=0.2 \ddagger \\
C V=6.3 \% \ddagger\end{array}$ & & & & & \\
\hline 1987 & & & & & & & & & $1987 t$ & & \\
\hline Late 1986 irrigation & 2 & 2 & 2 & 2 & 0 & (1) Standard & $8.92 \mathrm{a}$ & $(100)$ & 46 & $(100)$ & 5.2 \\
\hline Prior to $4 / 2$ harvest & 1 & 1 & 1 & 1 & 1 & (2) Wet & $8.70 \mathrm{a}$ & (98) & 54 & (117) & 6.2 \\
\hline Prior to $5 / 7$ harvest & 1 & 1 & 1 & 1 & 1 & (3) Dry & $7.98 \mathrm{~b}$ & (89) & 37 & (80) & 4.6 \\
\hline Prior to $6 / 11$ harvest & 2 & 3 & 2 & 2 & 2 & (4) July/Aug skip & $7.01 \mathrm{C}$ & (79) & 33 & (72) & 4.7 \\
\hline Prior to $7 / 9$ harvest & 2 & 3 & 1 & 2 & 2 & (5) July termination & $6.34 c$ & (71) & 23 & (50) & 3.6 \\
\hline Prior to $8 / 5$ harvest & 2 & 2 & 1 & 0 & 0 & LSD. $05=0.8 \ddagger$ & & & & & \\
\hline Prior to $9 / 4$ harvest & 2 & 3 & 1 & 0 & 0 & $C V=6.3 \% \ddagger$ & & & & & \\
\hline Prior to $10 / 9$ harvest & 1 & 1 & 1 & 1 & 0 & & & & $1988+\S$ & & \\
\hline Total applied water & & & & & & (1) Standard & $7.22 \mathrm{abc}$ & $(100)$ & 31 & $(100)$ & 4.3 \\
\hline acre-inches ${ }^{\star}$ & 46 & 54 & 37 & 33 & 23 & (2) Wet & $7.07 \mathrm{bc}$ & (98) & 31 & $(100)$ & 4.4 \\
\hline 1988 & & & & & & (3) Dry & $7.64 \mathrm{a}$ & (106) & 33 & (94) & 4.3 \\
\hline Late 1987 irrigation & 1 & 1 & 1 & 1 & 0 & (4) July/Aug skip & $7.32 \mathrm{ab}$ & (101) & 33 & $(106)$ & 4.5 \\
\hline Prior to $3 / 25$ harvest & 1 & 1 & 1 & 1 & 1 & (5) July termination & $7.15 \mathrm{bc}$ & (99) & 30 & (97) & 4.2 \\
\hline Prior to $5 / 16$ harvest & 1 & 1 & 1 & 1 & 1 & & & & & & \\
\hline Prior to $6 / 8$ harvest & 1 & 1 & 1 & 1 & 1 & LSD. $05=0.4 \ddagger$ & & & & & \\
\hline Prior to $7 / 7$ harvest & 2 & 2 & 2 & 2 & 2 & $C V=4.2 \% \neq$ & & & & & \\
\hline Prior to $8 / 4$ harvest & 2 & 2 & 2 & 2 & 2 & \multirow{4}{*}{\multicolumn{6}{|c|}{$\begin{array}{l}\text { *For each year's data, values within a column followed by a common letter do not } \\
\text { differ significantly at the } 5 \% \text { level of probability using LSD. } \\
\text { †Rainfall for the winter of } 1985 / 86 \text { was } 14 \text { inches; for } 1986 / 87 \text { was } 9 \text { inches; and } \\
\text { for } 1987 / 88 \text { was } 6 \text { inches. } \\
\text { fLeast significant differences at the } 5 \% \text { level of probability, and coefficients of } \\
\text { variation were calculated for tons/acre only. } \\
\text { §All treatments irrigated equally in } 1988 \text {. }\end{array}$}} \\
\hline Prior to $9 / 1$ harvest & 1 & 1 & 1 & 1 & 1 & & & & & & \\
\hline $\begin{array}{l}\text { Total applied water } \\
\text { acre-inches }\end{array}$ & 31 & 31 & 33 & 33 & 30 & & & & & & \\
\hline $\begin{array}{l}\text { "In-line flow meters me } \\
\text { vided by the number o } \\
\text { gations. }\end{array}$ & $\begin{array}{l}\text { d water ap } \\
\text { ks irrigated }\end{array}$ & $\begin{array}{l}\text { d per } \\
\text { otal we }\end{array}$ & $\begin{array}{l}\text { ation } \\
\text { applie }\end{array}$ & $\begin{array}{l}\text { twhich was } \\
\text { is the sum }\end{array}$ & $\begin{array}{l}\text { as then di- } \\
\text { of the irri- }\end{array}$ & & & & & & \\
\hline
\end{tabular}




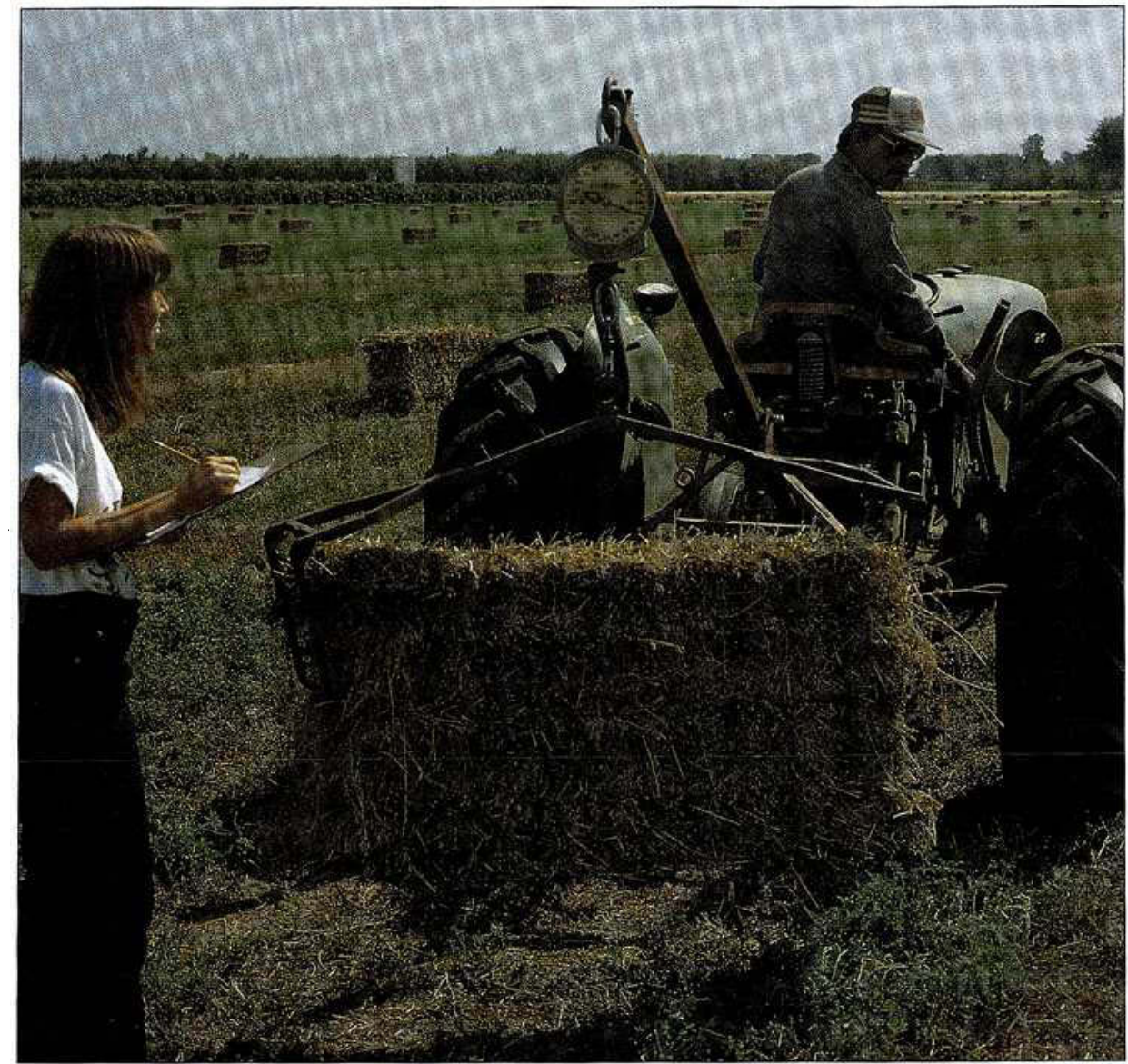

Field assistant Garnett Cooke and agricultural technician Francisco Correa weigh bales at Kearney Agricultural Center.

TABLE 3. Quality analyses of hay samples from the first harvest following re-watering of irrigation skip and termination treatments, alfalfa irrigation trial, Kearney Agricultural Center, Parlier, California*

\begin{tabular}{|c|c|c|c|c|c|c|c|c|}
\hline \multirow[b]{3}{*}{ Treatment } & \multicolumn{7}{|c|}{ Harvest dates } & \multirow[b]{3}{*}{ ADF } \\
\hline & \multicolumn{3}{|c|}{ October 8, 1986} & \multicolumn{4}{|c|}{ October 9,1987} & \\
\hline & TDN & $\begin{array}{l}\text { Crude } \\
\text { protein }\end{array}$ & MCF & ADF & TDN & $\begin{array}{l}\text { Crude } \\
\text { protein }\end{array}$ & MCF & \\
\hline \multirow[b]{2}{*}{$\begin{array}{l}\text { (4) July-Aug skip } \\
\text { (1) Standard }\end{array}$} & \multicolumn{8}{|c|}{ (n) } \\
\hline & $\begin{array}{l}53.9 \\
54.4\end{array}$ & $\begin{array}{l}21.1 \\
19.5\end{array}$ & $\begin{array}{l}22.3 \\
21.7\end{array}$ & $\begin{array}{l}31.9 \\
31.4\end{array}$ & $\begin{array}{l}55.9 \\
54.5\end{array}$ & $\begin{array}{l}22.3 \\
19.7\end{array}$ & $\begin{array}{l}19.9 \\
21.5\end{array}$ & $\begin{array}{l}30.8 \\
33.2\end{array}$ \\
\hline \multirow{4}{*}{$\begin{array}{l}\text { LSD. } 05 \dagger \\
\text { CV \% } \neq\end{array}$} & NS & 0.96 & NS & NS & NS & $\begin{array}{l}1.65 \\
5.0\end{array}$ & $\begin{array}{l}1.42 \\
4.0\end{array}$ & $\begin{array}{l}1.77 \\
3.4\end{array}$ \\
\hline & \multicolumn{8}{|c|}{ Harvest dates } \\
\hline & \multicolumn{3}{|c|}{$\begin{array}{l}\text { April 2, } 1987 \\
\text { Crude }\end{array}$} & \multicolumn{5}{|c|}{$\begin{array}{l}\text { March 25, } 1988 \\
\text { Crude }\end{array}$} \\
\hline & TDN & Protein & MCF & ADF & TDN & Protein & MCF & ADF \\
\hline $\begin{array}{l}\text { (5) July termination } \\
\text { (1) Standard }\end{array}$ & $\begin{array}{l}56.3 \\
52.9\end{array}$ & $\begin{array}{l}21.2 \\
18.5\end{array}$ & $\begin{array}{l}19.5 \\
23.5\end{array}$ & $\begin{array}{l}29.2 \\
32.9\end{array}$ & $\begin{array}{l}57.6 \\
55.9\end{array}$ & $\begin{array}{l}19.8 \\
18.2\end{array}$ & $\begin{array}{l}18.0 \\
20.0\end{array}$ & $\begin{array}{l}28.9 \\
31.7\end{array}$ \\
\hline $\begin{array}{l}\text { LSD.05† } \\
\text { CV \% }\end{array}$ & $\begin{array}{l}0.60 \\
0.5\end{array}$ & $\begin{array}{c}.64 \\
1.4\end{array}$ & $\begin{array}{r}.60 \\
1.2\end{array}$ & $\begin{array}{l}.54 \\
0.8\end{array}$ & $\begin{array}{l}1.36 \\
1.5\end{array}$ & $\begin{array}{l}1.04 \\
3.5\end{array}$ & $\begin{array}{l}1.59 \\
5.1\end{array}$ & $\begin{array}{l}1.79 \\
3.6\end{array}$ \\
\hline $\begin{array}{l}\text { QQuality analyses w } \\
\text { dry matter basis. } \\
\text { †Least significant di } \\
\ddagger \text { Coefficient of varia }\end{array}$ & $\begin{array}{l}\text { rmined } \\
\text { at the } \\
\text { ressed }\end{array}$ & $\begin{array}{l}\text { ing near it } \\
\text { level of } p \\
\text { a percent }\end{array}$ & $\begin{array}{l}\text { ared refle } \\
\text { Jability. }\end{array}$ & ance sp & troscopy & and are pre & sented on & a $90 \%$ \\
\hline
\end{tabular}

the applied water compared to the standard. In 1987, this treatment produced $89 \%$ of the standard treatment yield with $80 \%$ of the water applied. The apparently more efficient water use in 1986 compared to 1987 could be attributed to more residual soil moisture in 1986 following a winter with 14 inches of precipitation compared to only 9 inches in the winter of 1986-87.

In 1988, when all treatments were irrigated uniformly, final season yields were not significantly different from the standard. However, the dry treatment produced significantly more total hay than the wet and July termination treatments. This may have been due to a healthier root system compared to the wet treatment and a more extensive root system compared to the July termination treatment.

The amount of water applied to produce a ton of alfalfa hay was lower for the dry, skip, and termination treatments than for the standard and wet treatments in the first two years of the trial (table 2).

Whether this reduction in applied water at the expense of yield is profitable depends on hay prices and cost of water. The wet treatment demonstrated that under a nonsaline situation there is no benefit to overwatering alfalfa. Although more water was applied in the wet treatment than in the standard, yields were the same, indicating that either additional water was not needed or that it was lost through. deep percolation below the root zone.

There were differences between 1986 and 1987 in applied water per ton of dry matter produced for the dry, skip, and termination treatments. This could be due to the larger amount of rainfall in the winter preceding the 1986 production year compared to winter precipitation prior to the 1987 season. More water reserves in the soil resulted in increased growth when applied water fell short of crop needs.

Stress resulting from reduced irrigation did not have long-term effects on the ability of the crop to use applied water as shown by the 1988 data in table 2 . When normal irrigation was resumed, all treatments used approximately the same amount of applied water to produce the same forage yield.It is important to remember that this trial was intended to evaluate impact on yield due to less than optimum irrigation strategies. The purpose and design of the experiment was not to study water-use efficiency. The largescale design, method used for measuring applied water, and harvesting techniques were not to the level of detail needed for crop water use studies. Such studies would include direct measurements of soil water depletion, exact and total control of all water applied to plots (large-scale plots and soil variability in this trial made such 
control very difficult), and harvesting methods that precluded any loss of yield due to raking and baling. Rather, this trial was designed to look at large-scale effects of very different management strategies that could easily be adapted at the farm production level. For this purpose, applied water was measured within the limits of available resources to estimate approximate amounts used by each strategy.

Water management affected yield much more than quality under the conditions of this trial. In general, hay quality was not significantly affected by irrigation treatments except when water stress became severe and then quality declined. The commercial practices of raking and baling used for this study would have masked minor differences in quality due to water stress. However, better hay quality was detected for skip and termination treatments in the first harvest following reirrigation (table 3). For example, crude protein analyses of the July-August skip treatment were $21.1 \%$ and $22.3 \%$ compared to $19.5 \%$ and $19.7 \%$ for the standard treatment in the October harvests of 1986 and 1987, respectively. The increase in quality at these cuttings was due to observed maturity differences. Once drought-induced plots were rewatered, initiation of plant growth was delayed compared to the standard, resulting in less mature, higher quality alfalfa at the time of cutting.

Results from this trial indicate that alfalfa planted in early fall can survive induced first and second year midsummer drought from irrigation cutoff and subsequently return to normal production within two cuttings after rewatering. Following two years of imposed summer drought, stressed treatments produced yields equivalent to the standard treatment in the third year of production during which all treatments were irrigated normally.

Results from this study could also be useful in helping growers make management decisions on how to utilize limited water resources. Yield responses to different management strategies, water costs, and alfalfa hay prices must all be considered in order to determine which method is most profitable.

\section{A. Frate is Farm Advisor, Tulare County;}

B. A. Roberts is Farm Advisor, Kings County, and V. L. Marble is Specialist, Department of Agronomy, UC Davis

The authors acknowledge the assistance of John Peterson, Field Supervisor, Kearney Agricultural Center; Joe Padilla, Field Technician, Kings County; John Soares and Brett Allen, Field Technicians, Tulare County; and the Dairymen's Creamery Cooperative Association.

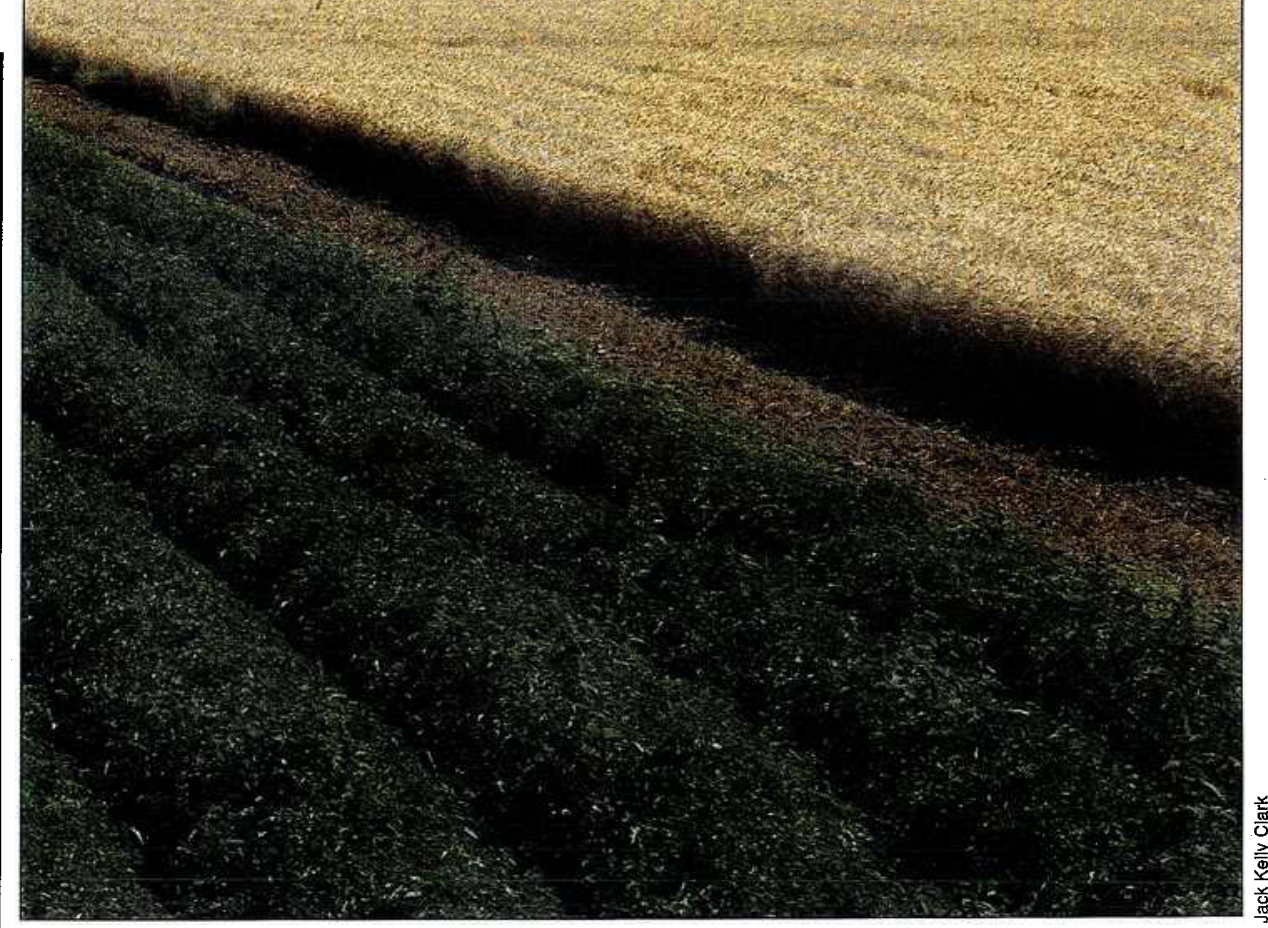

Diversification: tomato crop grows next to wheat fields.

\title{
New index measures returns to risk in crop production
}

\author{
Steven C. Blank
}

\section{Now crop producers have an index that predicts returns from risk in agriculture. Adapted from stock portfolio strategies, the index is one of the first to be applied to farming. Crop diversification will be described as a risk manage- ment strategy and evaluated using the index with data from three sample counties.}

Selecting which crops to produce is one of the most important decisions faced by agricultural producers, yet many do not understand the risks associated with that decision. Too often their analysis stops once a market opportunity has been identified. Besides the profit they anticipate, producers need to consider the relative risks associated with each crop to accurately assess market opportunities. The many agricultural crops produced and marketed profitably by California growers are by no means equal in posing risks. For growers to select crops that best suit their needs, they must take account of these differences. Unfortunately, strategies that lower risk usually reduce expected net returns.
Growers should consider the risk/return tradeoff when making cropping decisions.

This article provides information about income risks associated with major California crops and how to manage those risks. We have also included an index that decision makers can use to account for the risk/return tradeoff when designing risk management strategies.

First, income risk is described, followed by a brief summary of risk measurements for a sample of crops. Next, diversification into a portfolio of crops is presented as a risk management strategy. As illustrations, we present data reflecting historical income risk levels using measures of returns to risk for crop portfolios in three counties. Finally, some traditional crop rotations from those counties are evaluated, using portfolio methods as an example of how the returns-to-risk index can facilitate cropping decisions.

\section{Income risks faced by crop producers}

"Risk" is usually defined as "volatility" or "fluctuation." Income risk faced by agricultural producers reflects the net effects of risks associated with (1) production and yield and (2) marketing and price. 